\title{
Comparison between the effect of $\gamma$-irradiation and roasting on the profile and antioxidant activity of wheat germ lipids
}

\author{
By Mohamed Fawzy Ramadan ${ }^{1 *}$, Hany El-Said Showky ${ }^{2}$ \\ and Abd El-Rahman Mohamed Sulieman ${ }^{3}$
}

\author{
${ }^{1}$ Agricultural Biochemistry Department, Faculty of Agriculture, \\ Zagazig University, 44511 Zagazig, Egypt \\ ${ }^{2}$ The Egyptian Atomic Energy Authority, Nuclear Research Centre (NRC), Cairo, Egypt. \\ ${ }^{3}$ Food Science Department, Faculty of Agriculture, Zagazig University, 44511 Zagazig, Egypt. \\ ( ${ }^{*}$ corresponding author: hassanienmohamed@yahoo.com).
}

\section{RESUMEN}

Comparación entre el efecto de la $\gamma$-irradiación y el horneado en el perfil y en la actividad antioxidante de los lípidos del germen de trigo.

Se estudió el efecto de la $\gamma$-irradiación (dosis de irradiación de $1 / 4,1 / 2$ y $1 \mathrm{kGy}$ ) y del horneado $\left(160^{\circ} \mathrm{C}\right.$ durante 20 min) en los componentes lipídicos del germen de trigo, un subproducto rico en nutrientes de la industria harinera. Ninguno de los tratamientos empleados tuvo un efecto significativo ni en el total de los lípidos recuperados ni en su composición en ácidos grasos. Los ácidos grasos mayoritarios fueron el ácido linoleico, seguido de los ácidos oleico y palmítico. Un aumento del contenido de ácidos grasos libres caracterizó el perfil lipídico de las muestras irradiadas. Las propiedades antiradicalarias de los lípidos de las muestras irradiadas y horneadas fueron estudiadas analizando el blanqueo del radical estable 1,1-difenil-2-picrilhidrazilo. Los lípidos de las muestras irradiadas exhibieron un potencial antiradicalario superior a los lípidos del germen de trigo horneado. Estos resultados sugieren que la $\gamma$-irradiación puede ser aplicada a la estabilización del germen de trigo, si bien la irradiación empleada podría estar limitada a $1 / 4 \mathrm{kGy}$.

PALABRAS-CLAVE: Ácidos grasos - Actividad antiradicalaria - Horneado - $\gamma$-Irradiación - Germen de trigo - Tocoferoles - Triricum aestivum.

\section{SUMMARY}

Comparison between the effect of $\gamma$-irradiation and roasting on the profile and antioxidant activity of wheat germ lipids.

In order to utilize wheat germ, a nutrient-dense byproduct of the wheat milling industry, in various food products, different treatments are used to investigate and stabilize its influence on lipid characteristics. However, there are no reports on the effect of $\gamma$-irradiation on the lipid profile of wheat germ. In this study, the impact of $\gamma$-irradiation (at radiation doses $1 / 4,1 / 2$ and $1 \mathrm{kGy})$ and roasting at $\left(160^{\circ} \mathrm{C}\right.$ for $20 \mathrm{~min}$ ) on the lipid constituents of wheat germ was examined. Both thermal and irradiation treatments did not have a significant effect on the total lipid recovery or the fatty acid composition of wheat germ lipids. The fatty acid profile was found to be made up of linoleic followed by oleic and palmitic as the major fatty acids. An increase in the content of free fatty acids characterized the lipid profile of the irradiated wheat germ samples. Antiradical properties of lipids from roasted and irradiated samples were analyzed using the bleaching of the stable 1,1-diphenyl-2picrylhydrazyl radical (DPPH). Lipids from irradiated samples exhibited relatively stronger radical scavenging potential than lipids from roasted wheat germ. It has been concluded that $\gamma$ irradiation could be applied for wheat germ preservation, where it might be limited to a dose of 1/4 kGy in the processing.

KEY-WORDS: Fatty acids - $\gamma$-irradiation - radical scavenging activity - Roasting - tocopherols - Triricum aestivum - Wheat germ.

\section{INTRODUCTION}

Wheat germ, one of the major by-products of the flour milling industry, is a relatively cheap source of vitamins, minerals, dietary fibers, proteins, and several micronutrients. Germ constitutes about 2-3 $\mathrm{g} / 100 \mathrm{~g}$ of the wheat grain and can be separated in a fairly pure form from the grain during milling. Wheat germ contains about $11 \mathrm{~g} / 100 \mathrm{~g}$ oil (Sonntag, 1979) which is strongly flavored, expensive and easily perishable. The oil contains the following fatty acids: linoleic acid $(55 \mathrm{~g} / 100 \mathrm{~g})$, palmitic acid (16 g/100 g), oleic acid ( $14 \mathrm{~g} / 100 \mathrm{~g}$ ) and linolenic acid $(7 \mathrm{~g} / 100 \mathrm{~g})$. The oil is used in products such as food, biological insect control agents, pharmaceuticals and cosmetic formulations. It is currently applied in the feed industry in large amounts to produce various animal feeds. It has been well recognized as one of the richest natural sources of vitamin $E$ and would be therefore considered an ideal candidate for largescale preparation of vitamin E (Kahlon, 1989; Ge et al., 2002).

The dense nutrient concentration and high palatability of wheat germ make it suitable for the enrichment of processed foods. However, wheat germ has poor shelf life due to the presence of unsaturated fatty acids, and oxidative and hydrolytic enzymes, rendering the product highly susceptible to rancidity (Dunford and Zhang, 2003). Several 
attempts have been made to develop processes for stabilizing and improving the shelf life of wheat germ, which include steaming and toasting, microwave heating, packaging into three-layer composite paper bags with polyethylene coating, infrared heating and antioxidant treatment. Few of the processes pertaining to the treatment of wheat germ towards its stabilization are patented (Sudha et al., 2007).

Exposure to ionizing radiation such as $\gamma$-rays provides an effective method for preservation. It is a non-thermal process and leaves no toxic residue. Increasing importance is being accorded to food irradiation the world over in order to counteract the prevalence of food borne illness. One major drawback to the irradiation of high-fat-containing foods is the production of off-odor due to the radiation-induced breakdown of lipids (Niyas et al., 2003).

To the best of our knowledge, there are no reports so far on the impact of radiation on wheat germ lipids. Because wheat germ is a high-fatcontaining material, it was of interest to ascertain whether changes in any of the lipid characteristics may be dose dependent. The present work, therefore, attempts to determine the changes, if any, in the profile and antiradical properties of lipids extracted from irradiated wheat germ in comparison with roasted wheat germ.

\section{MATERIAL AND METHODS}

\subsection{Materials}

Untreated raw wheat (Triricum aestivum) germ purchased from a local flour mill was carefully cleaned to remove contaminates. The germ collected was stored in an airtight container in a freezer $\left(-20^{\circ} \mathrm{C}\right)$ until it was further used for different experiments. Standards used for vitamin $E(\alpha-, \beta-$, $\gamma$ - and $\delta$-tocopherol) were purchased from Merck (Darmstadt, Germany). 1,1-diphenyl-2picrylhydrazyl (DPPH, approximately $90 \mathrm{~g} / 100 \mathrm{~g}$ ) was from Sigma (St. Louis, Mo, USA). Toluene of HPLC grade was used throughout the antiradical test. Reagents and chemicals used were of the highest purity available.

\subsection{METHODS}

\subsubsection{Treatment of the wheat germ}

Roasting. Twenty-five-gram samples were filled into tubes (34 mm i.d. $\times 100 \mathrm{~mm}$ ), sealed with screw caps (Teflon septum), and heated at $160 \pm$ $2{ }^{\circ} \mathrm{C}$ for $20 \mathrm{~min}$ in a drying oven. The roasted samples were cooled to room temperature and submitted to the extraction of lipids.

$\gamma$-Irradiation. Wheat germ was divided into three equal lots of $100 \mathrm{~g}$ each and then exposed to $\gamma$-radiation at $25{ }^{\circ} \mathrm{C}$ to overall average doses of $1 / 4$,
$1 / 2$, and $1 \mathrm{kGy}$ at a dose rate of $3.24 \mathrm{KGy} / \mathrm{h}$ using a

${ }^{60} \mathrm{Co}$ package irradiator. Samples were analyzed within 1 week of storage.

\subsubsection{Analysis of treated wheat germ}

The proximate composition of wheat germ such as moisture, total ash and crude protein was determined according to standard AOAC methods. Soxhlet extraction of wheat germ oil was carried out according to the AOCS Official methods $\mathrm{Ba}$ 3-38 using $n$-hexane (AOCS, 1998).

\subsubsection{Free fatty acids (FFA) analysis}

Free fatty acid (FFA) content as percentage of oleic acid was determined using the AOCS Official Method Ca5a-40 (1998). In addition, by means of preparative thin-layer chromatography (TLC) on Silica gel $F_{254}$ plates (thickness $=0.5 \mathrm{~mm}$; Merck, Darmstadt, Germany) a further characterization of neutral lipid classes including FFA was carried out with the solvent system $n$-hexane/diethyl ether/acetic acid (60:40:1, v/v/v). For the detection of the lipids, the TLC plates were sprayed with sulfuric acid (40 g/100 g). Each spot was identified with lipid standards as well as their reported retention factor $\left(R_{f}\right)$ values (Ramadan et al., 2006). The bands at $R_{f}$ values corresponding to FFA were visualized under ultraviolet light, scraped from the plate and recovered by extraction with chloroform/methanol (2:1, v/v). The fatty acid composition of FFA was determined by GLC as described below.

\subsubsection{Gas Liquid chromatography analysis of fatty acids}

Fatty acids were transesterified into methyl esters (FAME) using N-trimethylsulfoniumhydroxide (Macherey-Nagel, Düren, Germany) according to the procedure reported by Arens et al. (1994). FAME were identified on a Shimadzu GC-14A equipped with a flame ionization detector (FID) and C-R4AX chromatopac integrator (Kyoto, Japan). The flow rate of the carrier gas helium was 0.6 $\mathrm{mL} / \mathrm{min}$ and the split value with a ratio of $1: 40$. A sample of $1 \mu \mathrm{L}$ was injected onto a $30 \mathrm{~m} \times 0.25 \mathrm{~mm}$ $\times 0.2 \mu \mathrm{m}$ film thickness Supelco $\mathrm{SP}^{\mathrm{TM}}-2380$ (Bellefonte, PA, USA) capillary column. The injector and FID temperature were set at $250^{\circ} \mathrm{C}$. The initial column temperature was $100{ }^{\circ} \mathrm{C}$ programmed at $5{ }^{\circ} \mathrm{C} / \mathrm{min}$ to $175^{\circ} \mathrm{C}$ and kept at $175^{\circ} \mathrm{C}$ for $10 \mathrm{~min}$, then $8{ }^{\circ} \mathrm{C} / \mathrm{min}$ to $220^{\circ} \mathrm{C}$ and kept at $220{ }^{\circ} \mathrm{C}$ for $10 \mathrm{~min}$. In order to facilitate identification, a comparison was made between the retention times of the samples and those of the authentic standard mixture (Sigma, St. Louis, MO, USA; $99 \mathrm{~g} / 100 \mathrm{~g}$ purity specific for GLC), run on the same column under the same conditions. 


\subsubsection{Normal phase high performance liquid chromatography (NP-HPLC) separation, identification and quantification of tocopherols}

Procedure. NP-HPLC was selected to avoid extra sample treatment (e.g., saponification) according to Ramadan and Moersel (2002) and Ramadan-Hassanien (2004). The analysis was performed with a solvent delivery LC-9A HPLC (Shimadzu, Kyoto, Japan). The chromatographic system included a model 87.00 variable wavelength detector and a $250 \times 4 \mathrm{~mm}$ i.d. LiChrospher-Si 60, $5 \mu \mathrm{m}$, column (Knauer, Berlin, Germany). Separation of tocopherol isomers was based on isocratic elution when the solvent flow rate was maintained at $1 \mathrm{~mL} / \mathrm{min}$ at a column back-pressure of about 65-70 bar. The solvent system selected for elution was isooctane/ethyl acetate $(96: 4, \mathrm{v} / \mathrm{v})$ with detection at $295 \mathrm{~nm}$. Twenty $\mu \mathrm{L}$ of the diluted solution of $T L$ in the mobile phase were directly injected into the HPLC column. Tocopherol isomers were identified by comparing their retention times with those of authentic standards.

Preparation of standard curves. Standard solutions were prepared by serial dilution to concentration of approximately $5 \mathrm{mg} \mathrm{mL}^{-1}$ of each tocopherol isomer. Standard solutions were prepared from a stock solution which was stored in the dark at $-20{ }^{\circ} \mathrm{C}$. Twenty $\mu \mathrm{L}$ was injected and peak areas were determined to generate standard curve data.

Quantification. All quantification was by peak area using Shimadzu C-R6A chromatopac integrator (Kyoto, Japan). Standard curves (concentration versus peak area) were calculated from six concentration levels by linear regression. Based on the established chromatographic conditions, repeated injections of different concentrations of the standard tocopherols were made 3-times onto the HPLC system. Injections in triplicate were made at each concentration for both standards and samples. All work was carried out under subdued light conditions. All the experiments were repeated at least three times when the variation on any one was routinely less than $5 \%$.

\subsubsection{Radical-scavenging activity (RSA) of total lipids on DPPH-radicals}

Different solvents were used to assay the RSA of vegetable oils and the best results were achieved with toluene which was able to completely dissolve the hydrophobic and the hydrophilic compounds of the different oils under study. Therefore, the RSA of the oils was assayed with DPPH radicals previously dissolved in toluene according to Ramadan and Moersel (2006) and Ramadan et al. (2003). RSA and the presence of hydrogen donors in wheat germ oil samples after processing were examined by a reduction of DPPH in toluene. A toluenic solution of DPPH radicals was freshly prepared at a concentration of $10^{-4} \mathrm{M}$. The radical, in the absence of antioxidant compounds, was stable for more than $2 \mathrm{~h}$ of normal kinetic assay. For evaluation, $10 \mathrm{mg}$ of oil (in $100 \mu \mathrm{L}$ toluene at room temperature) was mixed with $390 \mu \mathrm{L}$ toluenic solution of DPPH radicals and the mixture was vortexed for $20 \mathrm{~s}$ at ambient temperature. Against a blank of pure toluene without DPPH, the decrease in absorption at 515 $\mathrm{nm}$ was measured in 1-cm quartz cells after 30,60 and $120 \mathrm{~min}$ of mixing using UV-260 visible recording spectrophotometer (Shimadzu, Kyoto, Japan). RSA toward DPPH radicals was estimated from the differences in absorbance of toluenic DPPH solution with or without sample (control) and the inhibition percent was calculated from the following equation:

$$
\begin{gathered}
\% \text { inhibition }=[(\text { absorbance of control }- \\
\text { absorbance of test sample }) / \text { absorbance } \\
\text { of control }] \times 100 .
\end{gathered}
$$

The data collected for each assay are the averages of three independent determinations, each carried out in triplicate, and the standard divisions were then calculated.

\section{RESULTS AND DISCUSSION}

Wheat germ, a nutritious by-product of the flour milling industry constituting 2.5-3.0 g/100 g of the grain can be separated in a fairly pure form by using a germ separator or by suitable adjustments in milling techniques. Wheat germ contains highly concentrated nutrients: 3 times as much protein, 7 times as much fat, 15 times as much sugar and 6 times as many minerals when compared to wheat flour. In addition, wheat germ is the richest source of tocopherols and a rich source of B-group vitamins, lysine and unsaturated fatty acids (Sudha et al., 2007). The results of the proximate chemical analysis indicated that raw wheat germ sample had ca. $11 \mathrm{~g} / 100 \mathrm{~g}$ moisture, ca. $31 \mathrm{~g} / 100 \mathrm{~g}$ crude protein, and ca. $18 \mathrm{~g} / 100 \mathrm{~g}$ dietary fiber. The total carbohydrate by difference was found to be 58 $\mathrm{g} / 100 \mathrm{~g}$, whereas the total lipids content of wheat germ was in the range of 7 to $8 \mathrm{~g} / 100 \mathrm{~g}$. The results indicated that both roasting and $\gamma$-irradiation does not bring about any alteration in the total lipid yield even at the highest radiation dose (1 kGy).

\subsection{Impact of roasting and irradiation on the fatty acid profile and free fatty acid contents}

The fatty acid composition of differently treated wheat germ samples was not affected by thermal or irradiation treatments. Six fatty acids were identified in wheat germ extracts (Table 1), where the analysis of FAME gave the proportion of linoleic followed by oleic and palmitic as the major fatty acids, which together comprise more than $92 \mathrm{~g} / 100$ $\mathrm{g}$ of the total identified FAME. A striking feature of wheat germ lipids was the relatively high level of polyunsaturated fatty acids (PUFA), especially 
Table 1

Fatty acid profile of wheat germ lipids under different treatment ${ }^{\text {a }}$

\begin{tabular}{cccccc}
\hline Fatty acid & Control & Roasted & $\mathbf{1 / 4}$ KGy & $\mathbf{1 / 2}$ KGy & $\mathbf{1}$ KGy \\
\hline C16:0 & $17.7 \pm 1.26$ & $17.3 \pm 1.34$ & $17.0 \pm 1.45$ & $17.1 \pm 1.23$ & $17.2 \pm 1.67$ \\
C16:1n-7 & $0.17 \pm 0.02$ & $0.27 \pm 0.03$ & $0.98 \pm 0.02$ & $0.97 \pm 0.09$ & $0.83 \pm 0.08$ \\
C18:0 & $0.55 \pm 0.12$ & $0.64 \pm 0.16$ & $0.55 \pm 0.05$ & $0.56 \pm 0.09$ & $0.62 \pm 0.04$ \\
C18:1n-9 & $18.1 \pm 0.92$ & $18.3 \pm 0.88$ & $18.0 \pm 0.96$ & $18.4 \pm 1.20$ & $18.5 \pm 0.98$ \\
C18:2n-6 & $57.4 \pm 2.22$ & $56.9 \pm 1.99$ & $57.5 \pm 1.89$ & $57.2 \pm 2.33$ & $57.1 \pm 1.98$ \\
C18:3n-3 $^{\text {S SFA }}$ & $6.08 \pm 0.78$ & $6.59 \pm 0.66$ & $5.97 \pm 0.89$ & $5.77 \pm 0.45$ & $5.75 \pm 0.34$ \\
S MUFA $^{\mathrm{c}}$ & 18.2 & 17.9 & 17.5 & 17.6 & 17.8 \\
S PUFA $^{d}$ & 63.6 & 18.5 & 18.9 & 19.3 & 19.3 \\
S/P $^{\mathrm{d}}$ & 0.28 & 03.6 & 63.6 & 63.1 & 62.9 \\
\hline
\end{tabular}

${ }^{a}$ Relative content $(\mathrm{g} / 100 \mathrm{~g})$. Results are given as mean $\pm \mathrm{SD}$ from triplicate estimations. ${ }^{\mathrm{b}}$ Total saturated fatty acids. ${ }^{\mathrm{c}}$ Total monounsaturated fatty acids. ${ }^{\mathrm{d}}$ Total polyunsaturated fatty acids. ${ }^{\mathrm{e}}$ Ratio of saturated to polyunsaturated fatty acids.

$\alpha$-linolenic fatty acid (ALA, C18:3n-3) which was estimated at higher levels. The total saturated fatty acids and PUFA content of wheat germ oil was about 18 and $63 \mathrm{~g} / 100 \mathrm{~g}$, respectively. It has been suggested that unsaturated fatty acid, especially PUFA intake reduces cardiovascular hearth disease (CHD) (Simopoulos, 1999). Several scientific studies have shown that $n-3$ fatty acids have benefits for lowering CHD risk (Hu, 2001). It has been also suggested that $n-3 / n-6$ ratio of 10 or less results in a reduction in fatal CHD risk (Dunford and Zhang, 2003; Hu, 2001). Wheat germ oil also has very high unsaturated and polyunsaturated fatty acid content and an excellent $n-3 / n-6$ fatty acid ratio (1/9). These results illustrate that under roasting conditions and the different irradiation treatments used for these experiments, isomerization and/or the oxidation of fatty acids did not occur.
The presence of fat hydrolyzing enzymes has made utilization of wheat germ very limited, in spite of it being a highly nutritious food product. In the present study, roasting and different irradiation treatments, commonly used by food industries, were given to the germ and their effect on free fatty acid levels in germ oil was studied. An increase in the FFA content could be clearly noted in the irradiated wheat germ samples especially those treated at doses above 1/4 kGy (Figure 1). This suggested a breakdown of acylglycerols during radiation processing, resulting in the release of free fatty acids. On the other hand, it was obvious that roasting was highly effective in completely inactivating the lipase activity . As recently reported (Sudha et al., 2007), different heat treatments, inactivated the lipase activity in germ completely. Various heat treatments inactivated lipoxygenase activity to varying extents (78-92\%). To determine

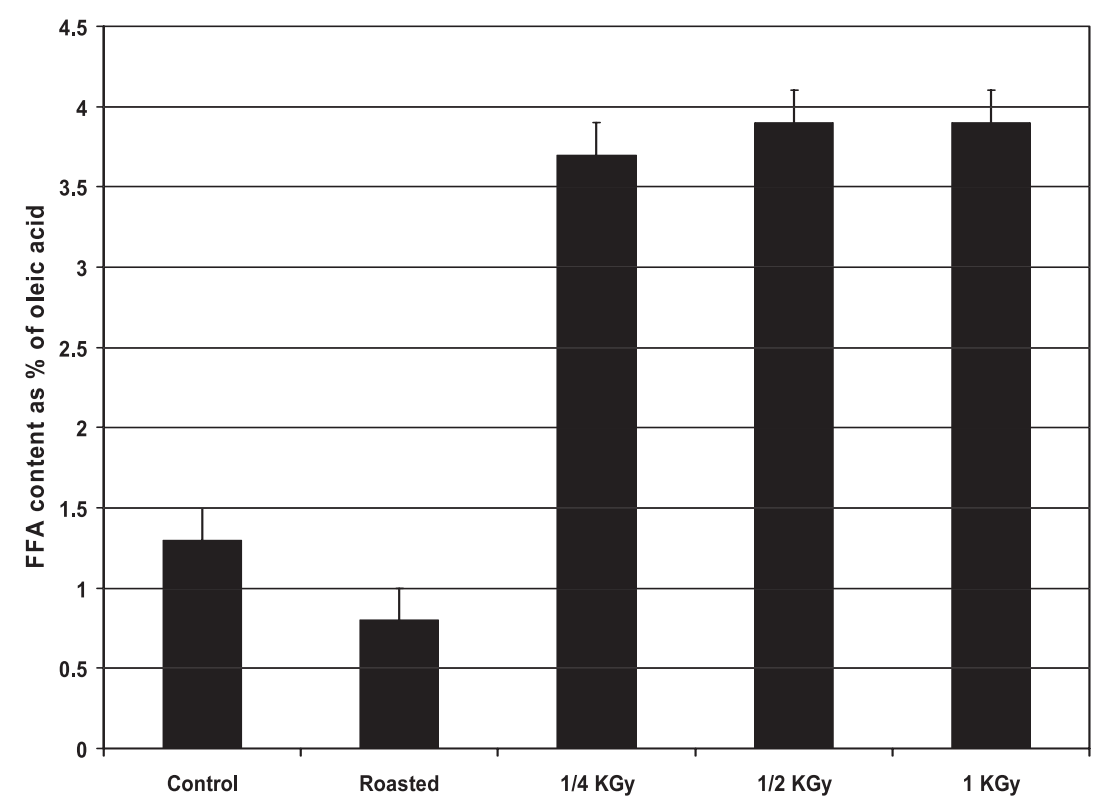

Figure 1

Changes in the levels of free fatty acids (\% of oleic acid) in different wheat germ lipids (on dry weight basis). Values given are the mean of three replicates. Error bars show the variations of three determinations in terms of standard deviation. 
the nature of the above fatty acids, the FFA $\left(R_{f} 0.56\right)$ present in both roasted and irradiated samples were isolated by preparative TLC. Linoleic followed by oleic and palmitic were also the major compounds identified, accounting for $90 \mathrm{~g} / 100 \mathrm{~g}$ of the total FFA (data not shown).

\subsection{Impact of roasting and irradiation on the tocopherol profile}

Nutritionally important components such as tocopherols improve oil stability. Tocopherols are the major lipid-soluble, membrane-localized antioxidants in humans. Deficiency of these compounds affects many tissues in mammalian and bird models. Vitamin E deficiency in humans causes defects in the developing nervous system of children and hemolysis in adults (Sokol, 1996). Eipdemiologic studies suggest that people with lower vitamin $\mathrm{E}$ and other antioxidant intake and plasma levels may be at an increased risk for certain types of cancer and for atherosclerosis (Gey et al., 1991; Rimm et al., 1993). It is also suggested that supplementation with antioxidants may decrease the risk of these and other degenerative processes (Kallio et al., 2002). Tocopherols in vegetable oils, moreover, are believed to protect PUFA from peroxidation (Kamal-Eldin and Andersson, 1997). The yield of tocopherols from wheat germ samples extracted by $n$-hexane were assessed by HPLC. In our investigation, an NP. HPLC technique was used to eliminate column contamination problems and allow the use of a general lipid extract for tocopherol isolation (Ramadan and Moersel, 2002). Thus, the saponification of oil samples was not required, which allowed shorter analysis time and greater stability during analysis. Most investigations on the tocopherol profile of wheat germ oil reported that $\alpha$ and $\beta$-tocopherols were the main tocopherols found in wheat germ but tocotrienols are probably absent from dissected germ and only occur in commercial germ as a result of bran and endosperm contamination (Ge et al., 2002). Data on the qualitative and quantitative composition of tocopherols are summarized in Table 2. Two of the four tocopherol isomers were present, wherein $\alpha$-tocopherol constituted ca. $59.3 \mathrm{~g} / 100 \mathrm{~g}$ of the total analytes. The rest being $\beta$-tocopherol (ca. 40.7 $\mathrm{g} / 100 \mathrm{~g})$. The obtained data suggested that the levels of tocopherols in the irradiated samples were relatively higher than those in the roasted samples. However, the observed difference was not significant. Roasting temperature $\left(160^{\circ} \mathrm{C}\right)$ might be able to increase the loss of thermally sensitive components in wheat germ lipids. $\alpha$-Tocopherol is the most efficient antioxidant of tocopherol isomers, while $\beta$-tocopherol has $25-50 \%$ of the antioxidative activity of a-tocopherol, and $\gamma$-isomer $10-35 \%$ (Kallio et al., 2002). Despite general agreement that a-tocopherol is the most efficient antioxidant and vitamin $\mathrm{E}$ homologue in vivo, studies, however, indicate a considerable discrepancy in its absolute and relative antioxidant effectiveness in vitro, especially when compared to $\gamma$-tocopherol (KamalEldin and Appelqvist, 1996). Levels of tocopherols detected in wheat germ lipids may contribute to the stability of the oil toward oxidation.

\subsection{Impact of roasting and irradiation on the antiradical activity of wheat germ lipids}

Autoxidation is a complex process, but model studies have revealed that the rate of autoxidation is affected by fatty acid composition, degree of unsaturation, the presence and activity of pro- and antioxidants, partial pressure of oxygen, the surface exposed to oxygen (dispersed systems) and storage conditions (Belitz and Grosch, 1999). Antioxidants inactivate reactive radicals at the initial steps of autoxidation, thus avoiding the propagation of the radical chain reaction. Radical scavengers have attracted special interest in nutrition and medicine, because they may protect human cells from free radicals, thereby preventing diseases, including cancer (Nakayama et al., 1993). Even though it is still not known whether these compounds are active against free radicals after being absorbed and metabolized by hepatic cells, radical-scavenging tests have gained acceptance for their rapid analysis of different materials. The present findings underline, however, that radicalscavenging activity and stabilization of food lipids should not be strictly correlated. Quantitative analysis of antioxidant power strongly depends on conditions; hence kinetics and endpoint of oxidation should be carefully considered (Frankel, 1993). Methods commonly evaluate the capability of an

Table 2

Tocopherol levels in the wheat germ lipids upon roasting and irradiation ${ }^{\text {a }}$

\begin{tabular}{lccccc}
\hline \multicolumn{1}{c}{ Compound } & Control & Roasted & $\mathbf{1 / 4}$ KGy & $\mathbf{1 / 2}$ KGy & $\mathbf{1 ~ K G y ~}$ \\
\hline$\alpha$-Tocopherol & $12.5 \pm 0.22$ & $12.3 \pm 0.19$ & $12.5 \pm 0.23$ & $12.6 \pm 0.18$ & $12.4 \pm 0.26$ \\
$\beta$-Tocopherol & $8.59 \pm 0.31$ & $8.37 \pm 0.25$ & $8.60 \pm 0.20$ & $8.51 \pm 0.15$ & $8.69 \pm 0.18$ \\
$\gamma$-Tocopherol & $\mathrm{ND}^{\mathrm{b}}$ & $\mathrm{ND}$ & $\mathrm{ND}$ & $\mathrm{ND}$ & $\mathrm{ND}$ \\
$\delta$-Tocopherol & $\mathrm{ND}$ & $\mathrm{ND}$ & $\mathrm{ND}$ & $\mathrm{ND}$ & $\mathrm{ND}$ \\
Total tocopherols & 21.09 & 20.67 & 21.10 & 21.11 & 21.09 \\
\hline
\end{tabular}

\footnotetext{
${ }^{a}$ Results (in $\mathrm{g} \mathrm{kg}^{-1}$ of total lipids)are given as the average of triplicate determinations \pm standard deviation. ${ }^{\mathrm{b}}$ Not detected.
} 
antioxidant, indirectly, by measuring the amount of lipid degradation products generated during the storage of a standard lipid. More recently, rapid tests based on radical scavenging have gained popularity. The decreasing absorption of a stable radical is measured, after the single occupied orbital is filled up with an electron provided by the antioxidant (Yen and Wu, 1999; Ramadan and Moersel, 2006).

Figure 2 show that lipids from irradiated wheat germ had relatively higher RSA than those from roasted and control samples. After $2 \mathrm{~h}$ incubation, $92.8 \%$ of DPPH radicals were quenched by bioactive lipids from irradiated (1/4 KGy) wheat germ, while bioactive lipids from the roasted sample were able to quench $91.4 \%$. However, the results demonstrate that there are a few differences between the roasting and irradiation on the antiradical properties of wheat germ lipids.

Antioxidant properties of wheat germ constituents are connected with the presence of tocopherols, which occur in high amounts (Barnes, 1982). According to Malecka (2002) $\Delta 5$-avenasterol covers $2-6 \%$ of demethylsterols of wheat germ oil and citrostadienol is the main component of its 4methylsterol fraction. Both compounds possess the ethyliden bound in the side chain, which is believed to be involved in the antioxidant action (Gordon and Magos, 1983). Among hydrocarbons present in wheat germ oil squalene was identified (Barnes, 1982). There is some evidence concerning its antioxidant activity, especially on heating (Sims et al., 1972; Malecka, 1994; Owen et al., 2000; Malecka, 2002).

Several natural antioxidants were reported to occur in wheat germ, especially in the lipid fraction, but most of them are expected to be degraded at elevated temperatures (Azizah et al., 1999); hence, the genuine stock of antioxidative compounds should be greatly reduced by roasting. However, the relatively strong RSA of lipids extracted from the roasted sample indicate that at least a part of the antioxidative principle was generated by Maillard type reactions that might have occurred at high temperatures between wheat germ constituents. On the other hand, Amadori compounds (Chuyen et al., 1998), reductones (Eichner, 1981; Singhara et al., 1998), amino reductones and Maillard-type polymers with antioxidative activity, are accumulated during the Maillard reaction (Kurata and Otsuka, 1998; Pischetsrieder et al. 1998). An antioxidative effect of the browning products of phospholipids was also reported (Husain et al., 1986; Krings et al., 2001).

\section{CONCLUSION}

With the recent clearance of irradiated products for local consumption, there is an ever increasing demand from producers and consumers for more information on the quality of irradiated products.

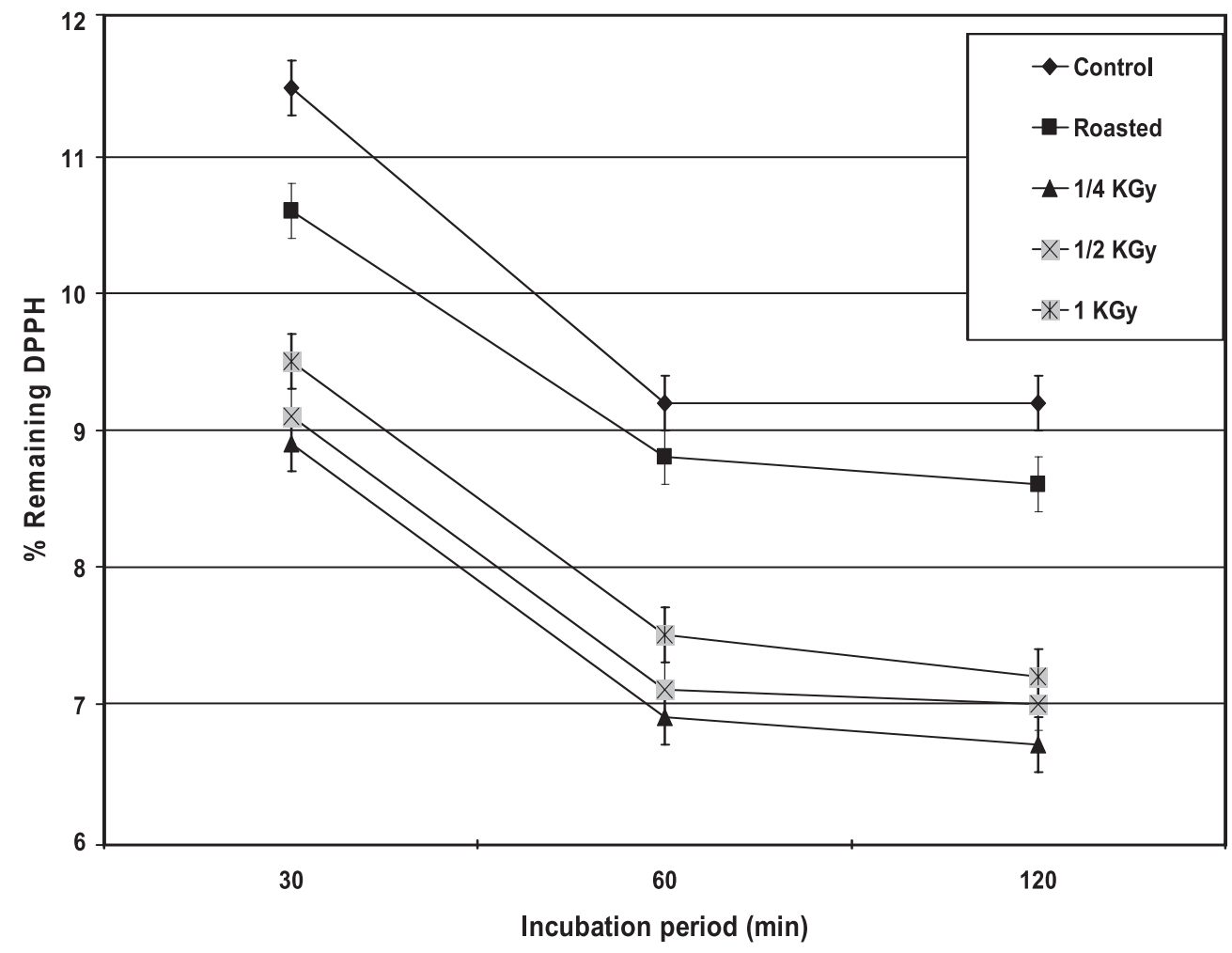

Figure 2

Scavenging effect during different incubation times of different wheat germ lipids on DPPH radicals as measured by changes in absorbance values at $515 \mathrm{~nm}$. Values given are the mean of three replicates and error bars show the variations of three determinations in terms of standard deviation. 
Wheat germ processing presents challenges due to its high content of PUFA and bioactive compounds. These compounds are prone to oxidation and degradation under the conditions used for conventional edible oil extraction and refining methods. The impact of $\gamma$-irradiation (as a safe method for food preservation) on the characteristics and radical scavenging activity of wheat germ lipids is reported for the first time. It could be concluded that $\gamma$-rays provide an effective alternative method when compared with roasting. Neither thermal treatment nor irradiation treatments greatly affected the fatty acid and tocopherol profile of the wheat germ lipids. The strong antiradical properties of lipids extracted from irradiated wheat germ may contribute to the stability of the oil toward oxidation. However, higher levels of FFA released during radiolysis at high doses might result in a discernible off-odor. 1/4 kGy might be considered a good dose for wheat germ processing. In consideration of potential utilization, detailed knowledge on the impact of $\gamma$-irradiation on the characteristics of wheat germ lipids is of major importance. Moreover, these findings will encourage us to further study the impact of roasting and irradiation on the oxidative stability of wheat germ during long storage.

\section{BIBLIOGRAPHY}

American Oil Chemistsã Society. Official Methods and Recommended Practices. 1998. $5^{\text {th }}$ ed., edited by Firestone D, American Oil Chemistsã Society, Champaign, IL (USA).

Arens M, Schulte E, Weber K. 1994. Fettsäuremethylester, Umesterung mit Trimethylsulfoniumhydroxid (Schnellverfahren). Fat Sci. Technol. 96, 6768.

Azizah AH, Nik Ruslawati NM, Swee Tee T. 1999. Extraction and characterisation of antioxidant from cocoa by-products. Food Chem. 64, 199-202.

Barnes PJ. 1982. Lipid composition of wheat germ and wheat germ oil. Fette Seifen Anstrichmittel 84, 256.

Belitz HD, Grosch W. 1999. Food Chemistry, $2^{\text {nd }}$ ed. Springer-Verlag, Berlin.

Chuyen NV, Ijichi K, Umetsu H, Moteki K. 1998. Antioxidative properties of products from amino acids or peptides in the reaction with glucose. In F. Shahidi, C.-T. Ho, and V. van Chuyen (Eds.), Process-Induced Chemical Changes in Food. Plenum Press: New York and London, pp. 201-212.

Dunford NT, Zhang M. 2003. Pressurized solvent extraction of wheat germ oil. Food Res. Int. 36, 905909.

Eichner K. 1981. Antioxidative effect of maillard reaction intemediates. Progress Food Nutr. Sci. 5, 441-451.

Frankel EN. 1993. In search of better methods to evaluate natural antioxidants and oxidative stability in food lipids. Trends Food Sci. Technol. 4, 220-225.

Ge Y, Yan H, Hui B, Ni Y, Wang S, Cai, T. 2002. Extraction of natural vitamin $E$ from wheat germ by supercritical carbon gioxide. J. Agric. Food Chem. 50, 685-689.

Gey KF, Puska P, Jordan P, Moser UK. 1991. Inverse correlation between plasma vitamin $\mathrm{E}$ and mortality from ischemic heart disease in cross-cultural epidemiology. Amer. J. Clin. Nutr. 53, 3245-3265.
Gordon MH, Magos P. 1983. The effect of sterols on the oxidation of edible oils. Food Chem. 10, 141.

Hu FB. 2001. The balance between omega- 6 and omega3 fatty acids and the risk of coronary heart disease. Nutr. 17, 741-742.

Husain SR, Terao J, Matsushita S. 1986. Effect of browing products of phospholipids on autoxidation of methyl linoleate. J. Amer. Oil Chem. Soc. 63, 457-460

Kahlon TS. 1989. Nutritional implications and uses of wheat and oat kernel oil. Cereal Foods World 34, 872-875.

Kallio H, Yang B, Peippo P, Tahvonen R, Pan R. 2002. Triacylglycerols, glycerophospholipids, tocopherols and tocotrienols in berries and seeds of two subspecies (ssp. sinensis and mongolica) of Sea buckthorn (Hippophaë rhamnoides). J. Agric. Food Chem. 50, 3004-3009.

Kamal-Eldin A, Andersson R. 1997. A multivariate study of the correlation between tocopherol content and fatty acid composition in vegetable oils. J. Amer. Oil Chem. Soc. 74, 375-380.

Kamal-Eldin A, Appelqvist LA. 1996. The chemistry and antioxidant properties of tocopherols and tocotrienols. Lipids 31, 671-701.

Krings U, El-Sahart YS, El-Zeany BA, Pabel B, Berger RG. 2001. Antioxidant activity of extracts from roasted wheat germ. Food Chem. 71, 91-95

Kurata T, Otsuka Y. 1998. Amino-reductones: formation mechanisms and structural characteristics. In: F. Shahidi, C.-T. Ho, and V. van Chuyen (Eds.), ProcessInduced Chemical Changes in Food. Plenum Press, New York and London, pp. 201-212.

Malecka M. 1994. The effect of squalene on the thermostability of rapeseed oil. Nahrung 38, 135.

Malecka M. 2002. Antioxidant properties of the unsaponifiable matter isolated from tomato seeds, oat grains and wheat germ oil. Food Chem. 79, 327-330.

Nakayama T, Yamada M, Osawa T, Kawakishi S. 1993. Suppression of active oxygen-induced cytotoxicity by flavanoids. Biochem.Pharmacol. 45, 265-267.

Niyas Z, Variyar PS, Gholap AS, Sharma A. 2003. Effect of $\gamma$-Irradiation on the lipid profile of nutmeg (Myristica fragrans Houtt.). J. Agric. Food Chem. 51, 6502-6504.

Owen RW, Mier W, Giacosa M, Hull WE, Spiegelhalder B, Bartsch HB. 2000. Phenolic compounds and squalene in olive oils: the concentration and antioxidant potential of total phenols, socoiridoids, lignans and squalene. Food Chem. Toxicol. 38, 647.

Pischetsrieder M, Schoetter C, Severin T. 1998. Formation of an aminoreductone during the Maillard reactrion of lactose with $\mathrm{N}$-acetyllysine or proteins. $J$. Agric. Food Chem. 46, 928-931.

Ramadan MF, Kroh LW, Moersel J-T. 2003. Radical scavenging activity of black cumin (Nigella sativa L.), coriander (Coriandrum sativum L.) and niger (Guizotia abyssinica Cass.) crude seed oils and oil fractions. J. Agric. Food Chem. 51, 6961-6969.

Ramadan MF, Moersel J-T. 2002. Direct isocratic normal phase assay of fat-soluble vitamins and $b$-carotene in oilseeds. Eur. Food Res. Technol. 214, 521-527.

Ramadan MF, Moersel J-T. 2006. Screening of the antiradical action of vegetable oils. J. Food Comp. Anal. 19, 838-842.

Ramadan MF, Sharanabasappa G, Seetharam YN, Seshagiri M, Moersel J-T. 2006. Characterisation of fatty acids and bioactive compounds of Kachnar (Bauhinia purpurea L.) seed oil. Food Chem. 98, 359365. 
Ramadan-Hassanien MF. 2004. Investigation on lipid composition and functional properties of some exotic oilseeds. ISBN 978-3-8325-0525-7, Logos Verlag, Berlin, Germany.

Rimm EB, Stampfer MJ, Ascherio A, Giovannucci E, Colditz GA, Willett WC. 1993. Vitamin E consumption and the risk of coronary heart disease in men. New Eng. J. Med. 328, 1450-1456.

Simopoulos AP. 1999. Essential fatty acids in health and chronic disease. Amer. J. Clinic. Nutr. 70, 560S-569S.

Sims RJ, Fioriti JA, Kanuk MJ. 1972. Sterols additives as polymerisation inhibitors for frying oils. J. Amer. Oil Chem. Soc. 49, 298.

Singhara A, Macku C, Shibamoto T. 1998. Antioxidative activity of brewed coffee extracts. In: Functional Foods for Disease Prevention II: Medicinal Plants and Other Foods (Vol. 702). American Chemical Society, Washington, DC, pp. 101-109.
Sokol RJ. 1996. Vitamin E. In: Present Knowledge in Nutrition, Ziegler EE, Filer LJ (eds): ILSI Press, Washington DC; 130-136.

Sonntag NOV. 1979. Composition and characteristics of individual fats and oils. In: D. Swern (Ed.), Bailey's Industrial Oil and Fat Products. Vol. 1 (pp. 284-477). New York: John Wiley and Sons.

Sudha ML, Srivastava AK, Leelavathi K. 2007. Studies on pasting and structural characteristics of thermally treated wheat germ. Eur. Food Res. Technol. 225, 351-357.

Yen GC, Wu J-Y. 1999. Antioxidant and radical scavenging properties of extracts from Ganoderma tsugae. Food Chem. 65, 375-379.

Recibido: 30/10/07 Aceptado: 20/12/07 